\title{
Riders on the Storm:
}

\section{Wales, the Union, and Territorial Constitutional Crisis}

\author{
RICHARD RAWLINGS*
}

The UK continues to undergo a rapid process of constitutional change, with an ongoing redistribution of law-making and governmental powers to different parts of the Union under an expanded rubric of 'devolution'. The paper illuminates a pervasive sense of territorial constitutional crisis and opportunity in the most recent period, familiarly associated with, but not confined to, Scotland. Constructive and flexible federal-type responses inside a famously uncodified constitution are championed. Wales, commonly treated as a junior partner in the UK, presents special challenges for constitutional and legal analysis and distinctive perspectives on the Union which have not received the attention they deserve. In tackling this deficiency, the paper elaborates a 'new Union' concept of a looser and less hierarchical set of constitutional arrangements in which several systems of parliamentary government are grounded in popular sovereignty and co-operate for mutual benefit.

\section{TIME TRIP}

The music of 'Riders on the Storm' takes us back over forty years, to in British public life the Royal Commission on the Constitution ('Kilbrandon'). ${ }^{1}$ The Commission had been established in the light of an early surge of nationalist sentiment in Scotland and Wales, as well as generalised complaint of too much centralisation in London. 'There was obviously', the Report solemnly intoned, 'some discontent with the workings of government'. ${ }^{2}$ Even though it largely sidestepped the Northern Ireland conflict, the Commission had a hard time. The instructions were vague, the inquiry seemingly endless, and, as shown in a comprehensive memorandum of dissent, the members fell out. The main question of devolution of powers from central government saw various schemes analysed for different parts of the UK and then disagreed about. And of course another generation would pass, and a certain Margaret Thatcher come and go, before Tony Blair's fresh-faced New Labour

\footnotetext{
* Faculty of Laws, UCL, Bidborough House, 38-50 Bidborough Street, London WC1H 9BT, United Kingdom.

r.rawlings@ucl.ac.uk
}

This article is a revised version of the Wales Governance Centre Annual Lecture delivered on 16 June 2015. I am grateful to Richard Wyn Jones and Adam Tomkins for their help; the usual disclaimer applies.

\footnotetext{
${ }^{1}$ Royal Commission on the Constitution 1969-1973, Vol. 1, Report (1973, Cmnd. 5460) (the Kilbrandon Commission). Recorded by Jim Morrison and the Doors in 1970, 'Riders on the Storm' features on the album L. A. Woman.

2 id., para. 1.
} 
government introduced devolution statutes for Scotland, Wales and Northern Ireland (again) at the turn of the century. ${ }^{3}$

\section{Legacy issues}

Nonetheless, looking at the 'Union' through contemporary eyes as the UK's voluntary association of four home countries, ${ }^{4}$ the legacy of Kilbrandon should not be discounted. Providing at one and the same time a mine of historical information and analysis, a source of constitutional inspiration, and a political and bureaucratic cautionary tale, the Commission's Report remains the last serious attempt by official sources to grapple with the overarching territorial architecture of this democratic multi- (pluri-) national state ${ }^{5}$ in a joined-up way.

Particularly striking from the comparative standpoint is the firm rejection of 'federalism' as a possible solution for the UK's apparent constitutional woes. 'Few of our witnesses advocated it, and people who know the system well tend to advise against it'. ${ }^{6}$ A slightly surprising conclusion, one might think, given that the rise of the Dominions and retreat from Empire had seen Britain conjuring federalism for many other peoples. For the avoidance of doubt, in rendering the federal idea in the UK dormant for several decades, Kilbrandon applied the strict conception of a full, formal 'federal system': 'sovereignty ... divided between two levels of government ... a written constitution ... basic terms ... "entrenched"”.

The Commission emphasised two objections which continue to resonate in this Atlantic archipelago. ${ }^{8}$ First (and ahead of much growth in judicial review), excessive legalism, or as might now be said, too much power for the UK Supreme Court. Second, 'the dominance of England' as currently constituted by some $85 \%$ of the UK population; and, in particular, the likely problems of governability or stand-offs with the UK Parliament if an English Parliament was created. Although typical of the time Kilbrandon had little to say about notions of English identity or nationhood, ${ }^{9}$ the Report also evidenced distaste for 'artificial division' into English regional assemblies. ${ }^{10}$ It prefigures a failure of New Labour proposals along these lines, with the notable exception of a directly elected Mayor and Assembly for Greater London. ${ }^{11}$

Kilbrandon established a small reservoir of general principles for reform of the territorial constitution, as conceived in terms of the distribution of powers and resources across the four home countries, and the relations between them, inside the UK. Perhaps the better adjective is 're-established' since it does not do to overlook the historical legacy of all those debates on home rule in Victorian times ${ }^{12}$ and later. ${ }^{13}$ Kilbrandon spoke of 'the need to preserve unity',

\footnotetext{
${ }^{3}$ Scotland Act 1998; Government of Wales Act 1998; and, a main ingredient in the ongoing peace process, Northern Ireland Act 1998.

${ }^{4}$ Or alternatively, avoiding association of the term 'Union state' with (the joining of) England and Scotland, as 'a state of unions': J. Mitchell, Devolution in the UK (2009). Par for the period, the Royal Commission visualised the UK in terms of a 'unitary state': Kilbrandon, op. cit., n. 1, para. 57.

${ }^{5}$ H. Kearney, The British Isles: A History of Four Nations (1989); Multinational Democracies, eds. A-G. Gagnon and J. Tully (2001); M. Keating, Plurinational Democracy (2004).

${ }^{6}$ Kilbrandon, op. cit., n. 1, para. 498.

${ }^{7}$ id., paras. 502, 505-506.

8 id., paras. 528-529, 531.

9 id., para. 186; and see in contrast, M. Kenny, The Politics of English Nationhood (2014).

10 id., para 532.

${ }^{11}$ Greater London Authority Act 1999; and see T. Travers, The Politics of London: Governing an ungovernable city (2004).

12 Ireland always, but extending to a dash of Cymru Fydd ('New Wales'); see K. Morgan, Revolution to

Devolution: Reflections on Welsh Democracy (2014) especially ch. 6.
} 
coupled with desirable 'flexibility' and 'good communication between government and people'. The Report duly integrated a key element of legitimacy - 'constitutional arrangements cannot be imposed against the will of the people' - and constitutional fundamentals such as preserving and fostering representative democracy and (as it would then have been put) 'the greatest regard for the liberty of the individual.' 14 To anticipate the argument, it would have been strange indeed if this appeal to constitutional theory and practice from a Royal Commission had gone unremarked in present-day debates over the Union.

The development of Welsh devolution also highlights a particular role for institutional memory in the shadow of Kilbrandon. Closed and elite forms of constitution-building later revealed, this is the story of how, pressed to give evidence, dominant forces in the Labour Party adopted the model of executive (not legislative) devolution and then, despite the inconvenient fact of minimal support for it on the Commission, clung to this approach in the ill-fated Wales Act 1978 and subsequent long years of Conservative government. ${ }^{15}$ Why reinvent the wheel? Carefully preserved in the bowels of the territorial department, official papers from the 1970s would duly be recycled - samizdat fashion - as John Major's administration tottered to destruction at the hands of New Labour. ${ }^{16}$

\section{Crisis and opportunity}

Self-evidently, the great wave of devolution launched by New Labour has not served to stabilise the internal constitutional architecture of the UK. To speak today of a pervasive sense of territorial constitutional crisis, let alone of constitutional unsettlement, ${ }^{17}$ or (in the words of the Oxford dictionary definition) of 'a time of intense difficulty or danger' for the Union, hardly exaggerates. The twin political facts that in the Scottish independence referendum ${ }^{18}$ some $45 \%$ voted to leave, and that an avowedly nationalist/separatist party has won victories in a UK general election on a scale not seen since Sinn Fein in 1918, cannot be wished away.

Harking back to the song-title, this ongoing political and constitutional storm, centred at least for the time being over Scotland, affords many opportunities. Not just for those who in properly democratic fashion promote the cause of independence, but also for reform of the UK's territorial constitution in terms of, in federal-style language, ${ }^{19}$ both 'shared rule' and 'self-rule'. Again, while driven to venture the elements, some parts are obviously less wellplaced than others to make the political and constitutional weather. In such conditions freeriding goes some way but only so far. As will be seen, Wales, commonly treated as a junior partner in the UK, exemplifies this aspect.

\section{CONSTITUTIONAL JOURNEY}

\footnotetext{
${ }^{13}$ As with the 1919-20 Speaker's Conference on Devolution: see A. Evans, 'Back to the Future? Warnings from History for a Future UK Constitutional Convention’ (2015) 86 Political Q. 24.

${ }^{14}$ Kilbrandon, op. cit., n. 1, paras. 416-421.

${ }^{15}$ R. Scully and R. Wyn Jones, Wales Says Yes: Devolution and the 2011 Welsh Referendum (2012) ch. 2.

${ }^{16}$ R. Rawlings, Delineating Wales (2003) ch. 2.

${ }^{17}$ V. Bogdanor, The crisis of the Constitution (2015); N. Walker, 'Our Constitutional Unsettlement' (2014) Public Law 529.

${ }^{18}$ See T. Mullen, 'The Scottish Independence Referendum 2014' (2015) 41 J. of Law and Society 627; and generally, J. Mitchell, The Scottish Question (2014).

${ }^{19}$ D. Elazar, Exploring Federalism (1987); M. Burgess, In Search of the Federal Spirit (2012).
} 


\section{Shifting gears}

What an extraordinary constitutional journey it has been for what I originally called in the pages of this journal 'The New Model Wales'. ${ }^{20}$ Triggered narrowly by referendum and inaugurated under the Government of Wales Act 1998, the first - executive - phase of Welsh devolution gave birth to a recognisably national polity. But offending the principle of separation of powers, representative and governmental functions were combined in the new National Assembly for Wales, which was itself limited to patchy secondary law-making powers based on previous territorial department functions. Developed via Part III of the Government of Wales Act 2006, a second - proto-legislative - phase established a mainstream structure of parliamentary government. Although more substantial powers were given to make or modify legislative provision, such 'Assembly Measures' were strictly confined to designated policy fields, as supplemented through a convoluted process of legislative competence orders. Activated under Part IV of the 2006 Act by convincing majority in another referendum, a third - fully legislative - phase continues with an intricate model of conferred powers: 'Acts of the Assembly' must sufficiently relate to subjects listed in the statute. While enabling primary law-making by the National Assembly, this model has proved a recipe for litigation at UK Supreme Court level. ${ }^{21}$ The Wales Act 2014 has also broken new ground in the fiscal constitution by establishing some Welsh taxing powers. ${ }^{22}$

Successive bouts of public criticism, followed by review and recommendation by independent Commission - Richard, ${ }^{23}$ Jones Parry, ${ }^{24}$ Holtham, ${ }^{25}$ Silk 1 and $2^{26}$ - underwrite the increasingly tired mantra that 'devolution is a process not an event'. At the heart of this ongoing constitutional debate in Wales have been concerns about coherence and clarity, ${ }^{27}$ effective policy delivery, and stability, subsidiarity and responsibility. The scale of the Welsh home-grown - autochthonous - development should not be overlooked, however. Future historians will surely remark on a whole series of domestic building blocks, for example major internal reform of organisational structures or innovative provision on sustainable development, equality and bilingualism. This aspect deserves special emphasis in view of a surrounding territorial constitutional turmoil which has, after all, been brewing for quite some time. To adapt a well-known local aphorism, ${ }^{28}$ Wales is an artefact which the Welsh partially produce; if they want to.

Published in 2003, my original monograph on Welsh devolution examined the early processes of establishing legal and political responsibilities, the creation of often skeletal institutional forms, the new relations with local government and public agencies, and the beginnings of post-devolution networks in civil society, under the title 'Delineating Wales'. ${ }^{29}$

\footnotetext{
${ }^{20}$ R. Rawlings, 'The New Model Wales' (1998) 25 J. of Law and Society 461.

${ }^{21}$ Local Government Byelaws (Wales) Bill 2012 - Attorney General Reference [2012] UKSC 53; Agricultural Sector (Wales) Bill - Attorney General Reference [2014] UKSC 43; Recovery of Medical Costs for Asbestos Diseases (Wales) Bill - Reference by the Counsel General for Wales [2015] UKSC 3.

22 The Welsh government has introduced the Tax Collection and Management (Wales) Bill to put in place the necessary institutional framework.

${ }^{23}$ Lord Richard (Chair), Report of the Commission on the Powers and Electoral Arrangements of the National Assembly (2004).

${ }^{24}$ Sir E. Jones Parry (Chair), Report of the All Wales Convention (2009).

${ }^{25}$ G. Holtham (Chair), Final Report of the Independent Commission on Funding and Finance for Wales (2010).

${ }^{26}$ P. Silk (Chair), Report of the Commission on Devolution in Wales, Part 1 (2012); Part 2 (2014).

${ }^{27}$ See further, Law Commission, Form and Accessibility of the Law Applicable in Wales (2015; CP 223).

${ }^{28} \mathrm{G}$. Williams, When Was Wales? (1985) at 304.

${ }^{29}$ Rawlings, op. cit., n. 16.
} 
With benchmarks thus to hand, it will soon be time properly to evaluate the internal maturation of the Welsh polity across the different phases under the fuller rubric of 'Constituting Wales'. A looming redesign of electoral arrangements for the National Assembly will be an exemplar, ${ }^{30}$ with issues of capacity/effectiveness and inclusiveness/ equitable treatment requiring careful assessment in terms of political responsibility and accountability. Wales in my view has an increasingly good story to tell; which is not to overlook major challenges as with economic development ${ }^{31}$ and public service delivery. ${ }^{32}$ Let us hope that new work on the interplay of constitution, values, politics and practice will be of interest not least to the many practitioners participating in a truly historic process for Wales perhaps without realising it.

\section{Wide horizons}

Let me refer to the 'UK's Changing Union' research project, based in Wales. Running for three years from 2012, the project has served to enrich our understanding of territorial politics, not least through partnership-working in England, ${ }^{33}$ and made an important series of targeted interventions in the Welsh devolutionary process. ${ }^{34}$ In light of the ferment in the UK's territorial constitution the fact of the project underwrites two different but related themes: the need for more considered responses than those hitherto on offer from the UK government, and the insufficiently well-known fact of Wales as a small but significant crucible of innovative constitutional thinking about the Union.

Putting this in perspective, fifteen years of experience with devolution have hardly served to blunt the familiar criticism of UK constitutional development as ad hoc and piecemeal: in light of a rapid, varied and ongoing redistribution of law-making and governmental powers to different parts of the Union, quite the reverse. The House of Lords Constitution Committee has castigated the unionist parties at Westminster for no coherent vision for the future shape of the UK and has expressed astonishment, no less, at the seeming failure of central government in Whitehall to think through the wider implications of further powers for Scotland. ${ }^{35}$ There is today a whole cottage industry of unofficial responses to territorial constitutional crisis - all those think tanks and lobby groups aiming to act as agents of change and settlement. Conditions in Wales have also been ripe, however, for a more considered approach in official circles to the design and workings of the UK's territorial constitution. It is not simply that in the last few years Wales has had the only devolved government wholly committed to the Union. For this junior member of the UK 'family' of countries, muddling through the territorial constitution commonly has negative connotations; more exchanges between Westminster and Holyrood, less, in the title of the original devolution White Paper, ${ }^{36}$ 'a voice for Wales'.

\footnotetext{
${ }^{30}$ National Assembly for Wales Commission, The Future of the Assembly (2015).

${ }^{31} \mathrm{G}$. Holtham et al, An economic strategy for Wales?(2015)

${ }^{32}$ Sir P. Williams (Chair), Report of the Commission on Public Service Governance and Delivery (2014).

${ }^{33}$ R. Wyn Jones et al, England and its two unions (2013).

${ }^{34}$ For example, UK's Changing Union Partnership, A stable, sustainable devolution settlement for Wales (2013); id, Size Matters: Making the National Assembly more effective (2013).

${ }^{35}$ House of Lords Constitution Committee, Tenth Report, Proposals for the devolution of further powers to Scotland, HL (2014-15)145, paras. 22, 24. See also, House of Commons Political and Constitutional Reform Committee, Eleventh Report, The future of devolution after the Scottish referendum. HC (2014-15) 700. The Constitution Committee has subsequently announced an inquiry into the 'Union and devolution': call for evidence, 24 July 2015.

${ }^{36}$ HM Government, A Voice for Wales (1997; Cm. 3718).
} 
First Minister of Wales Carwyn Jones has spoken of a 'new Union' mind-set, at heart the concept of a looser and less hierarchical set of constitutional arrangements in which several systems of parliamentary government are grounded in popular sovereignty and co-operate for mutual benefit. ${ }^{37}$ In contrast, that is, to a devolution mind-set or the assumption that the UK is fundamentally a centralised state. ${ }^{38}$ Viewed in comparative perspective, this is the realm of 'asymmetrical quasi-federalism', an ugly phrase which serves nonetheless to combine two creative elements of constitutional theory. On the one hand, the scope with distributed authority for territorial variation around a strong common core in the light of particular historic, economic and demographic factors; an aspect which has special resonance in Wales in view of the long dynamic of close integration with England. ${ }^{39}$ On the other hand, moving beyond the strict conception of federalism discountenanced by Kilbrandon, the broader reach of federal-type ideas of shared rule and self-rule in a flexible system of multi-level governance, where the First Minister has identified enabling unity while guaranteeing diversity as 'exactly the challenge we face' ${ }^{40}$ Future historians will no doubt wish to reflect on how these high level statements have played out in the Welsh government's evolving constitutional policy, as elaborated before the various independent Commissions, in the National Assembly, and to Westminster committees. Some may even be a little critical of this particular brand of new Union thinking for insufficient attention to localism within each nation, the evident potential of city regions, ${ }^{41}$ and, more broadly, the virtues of 'double devolution' (to and inside the country).

Several positive aspects of the new Union concept deserve special emphasis. In terms of the general direction of travel, the approach underscores the growth of federal-type elements in the UK constitution, epitomised today in moves statutorily to recognise the Scottish and Welsh devolved institutions as permanent features on the constitutional landscape. ${ }^{42}$ Secondly, mutual respect between the different legislatures inside the UK is a cardinal principle. While the routine workings of Dicey's doctrine of parliamentary sovereignty may suffice in England, Westminster, unless with the explicit assent of the devolved legislature and on a suitably generous reading of the well-known Sewel convention, ${ }^{43}$ should not normally legislate with regard to devolved matters or competence. Splendidly envisioned, this involves the abandonment of Anglo-centric and Metropolitan practices of what I have elsewhere called 'constitutional patriarchy'. ${ }^{44}$ Thirdly, a holistic view of the character and purposes of the Union is of the essence of this approach. Drawing for example on the admirably accessible analysis of the 2009 Calman report on Scottish devolution, ${ }^{45}$ attention is here drawn to the triple alliance of 'political union', as with representation of all parts at the centre; 'economic union', as with an integrated market underpinned by a single currency and central fiscal framework; and 'social union', as with a safety net of welfare benefits; to which

\footnotetext{
${ }^{37}$ See especially, Carwyn Jones, speech to the Institute for Government, 15 October 2014.

${ }^{38}$ If never a wholly unitary one; for the long view(s), see C. Kidd, Union and Unionisms (2008) and L. Colley, Acts of Union and Disunion (2013).

${ }^{39}$ J. Davies, A History of Wales (1993). For discussion of the countervailing dynamics of convergence and divergence across the three devolutionary frameworks, see D. Birell, Comparing Devolved Governance (2012).

${ }^{40}$ Carwyn Jones, 'Wales, the Union, and the Future', speech at the British Academy, 5 June 2015.

${ }^{41}$ For beginnings of the local version, see Welsh Government, City Regions: Final Report (2012).

${ }^{42}$ Scotland Bill 2015, clause 1; HM Government, Powers for a Purpose: Towards a lasting devolution settlement for Wales (2015; Cm. 9020), para. 2.2.4.

${ }^{43}$ Hansard, HL, col. 791 (21 July 1998). In placing the convention on a statutory footing, clause 2 of the Scotland Bill 2015 is however less generously drafted.

${ }^{44}$ R. Rawlings 'A Coalition Government in Westminster' in The Changing Constitution, eds. J. Jowell et al ( $8^{\text {th }}$ edn., 2015).

${ }^{45}$ Commission on Scottish Devolution, Serving Scotland Better: Scotland and the United Kingdom in the $21^{\text {st }}$ Century (2009), paras. 15-20.
} 
must of course be added 'security and defence union'. As one would expect from a Welsh Labour leader, the First Minister has placed particular stress on social solidarity and hence the need to preserve basic welfare entitlements as a core component of common citizenship. ${ }^{46}$

An alternative vision of a reformed Union has been sketched by Deputy Presiding Officer and Conservative Member of the National Assembly David Melding. ${ }^{47}$ The working assumption is that without a firm constitutional settlement, as in the form of a new Act of Union, unionism is destined to fail. Solid Burkean conservatism in terms of no clean break in the constitutional development, Melding propounds the idea of a federation deeply infused with (something called) the British parliamentary tradition. ${ }^{48}$ Read however in the particular context of Wales, this form of institutional imagining is perhaps more radical than at first appears; not so much historical patterns of assimilation with England, as flashes of a new Conservative brand of Welsh unionism. As part of a rich vein of federal-type ideas (re)surfacing in the Union's current predicament, ${ }^{49}$ Melding's contribution heralds efforts at legal consolidation and judicialisation.

One point on which our protagonists have agreed is the importance of constitutional timing and process. From 2012 on, the First Minister repeatedly called for a constitutional convention jointly sponsored by all four governments in the UK: in part to allow public participation; but in particular to facilitate joined-up thinking on the territorial constitution, rather than conversations in different rooms or bilateral reforms to particular constitutional arrangements; and further, of course, to ensure a seat for Wales at the table. This was coupled with clear warnings to the then Cameron-Clegg government: be proactive or risk being dictated to by events in Scotland. ${ }^{50}$ Nor could the Deputy Presiding Officer fairly be accused of constitutional shyness when messaging his Conservative colleagues in coalition in London. Such was the rhetoric, in hammering home the need for a constitutional convention, of the Union only surviving with a quick rewrite of the constitutional rulebook. ${ }^{51}$ These local soothsayers were fated to go unheeded in Whitehall, however, in the critical period ahead of the Scottish independence referendum. Such, it may be said, is the condition of Wales.

\section{THUNDER AND LIGHTNING}

The Cameron-Clegg administration, I recently wrote, ${ }^{52}$ will go down in history as the government which almost lost the Union. Permitted under the terms of the Edinburgh Agreement, ${ }^{53}$ a fine example of popular (Scottish) sovereignty had brought a complacent and then panicked Westminster elite virtually to its knees. If not the end, then strange days when,

\footnotetext{
${ }^{46}$ Jones, op. cit., n. 37. For an earlier set of studies, see Devolution and social citizenship in the UK, ed. S. Greer (2009).

${ }^{47}$ D. Melding, The Reformed Union: The UK as a Federation (2013).

48 id., ch. 2.

${ }^{49}$ For useful benchmarks, see S. Tierney, Constitutional Law and National Pluralism (2004) and D. Torrance, Britain Rebooted: Scotland in a Federal Union (2014).

${ }^{50}$ Carwyn Jones, 'Why the UK needs a constitutional convention', speech at Unlock Democracy, 12 July 2012. The idea would eventually make its way into Labour's 2015 election manifesto (at 63). For the unofficial Welsh version, see Institute of Welsh Affairs, Constitutional Convention Report (2015).

${ }^{51}$ Melding, op. cit., n. 47, ch. 6. See further, House of Commons Political and Constitutional Reform

Committee, Fourth Report, Do we need a Constitutional Convention for the UK? HC (2012-13) 371.

${ }^{52}$ Rawlings, op. cit., n. 44.

${ }^{53}$ Agreement between the United Kingdom Government and the Scottish Government on an Independence Referendum for Scotland (October 2012). See A. Tomkins, 'Scotland's choice, Britain's future' (2014) 130 Law Q. Rev. 215.
} 
at the thunderous height of an energising referendum campaign, the leaders of the main unionist parties vow major constitutional reform - 'devo more' or 'faster, safer and better change' for Scotland - in the Daily Record ${ }^{54}$ Among many noises off, the Smith Commission was conjured into existence, tasked with making recommendations for further devolution of powers to the Scottish Parliament. ${ }^{55}$ As a constitutional moment, ${ }^{56}$ September 2014 and all its works takes some beating.

Future historians will no doubt be busy tracing the changes in the constitutional weather, not least at the heart of the British political establishment in Westminster. Commonly whirring away in the background, the select committee system is a useful barometer. On from occasional forays in the territorial constitution, ${ }^{57}$ another cottage industry of reports would rapidly develop: oh-so belatedly. Predictably the product would be very variable: ranging from all those suitably august deliberations in the House of Lords to the last gasp efforts of a Labour-dominated Scottish Affairs Committee, ${ }^{58}$ and on through to a determinedly optimistic vision of fiscal devolution in England.$^{59}$ Not forgetting lumbering efforts at a draft written constitution, for which purpose, on an $800^{\text {th }}$ anniversary, the hallowed name 'Magna Carta' was naturally invoked. ${ }^{60}$ Paper was here being piled on paper.

The work of the Smith Commission and, underwriting the huge political stakes, an almost mechanical rendition of their proposals item by item in a Command Paper most hopefully titled Scotland in the United Kingdom: An enduring settlement, ${ }^{61}$ naturally commands attention. The process is an exemplar, on the one hand, of cross-party discussions with an independent chairman and tight timetable, hence scarce public involvement, many rough edges, but a deal nonetheless; and, on the other, of what has so concerned the Welsh First Minister, hence discrete territorial focus and likely knock-on effects for the rest of the UK. Then again certain recommendations, for example on the devolved legislature having competence over its own electoral arrangements, with the safeguard of super-majority decision-making, ${ }^{62}$ could happily be read across.

The Prime Minister's immediate and very public linking of more powers for Scotland with something called 'a fair settlement' for England will also linger long in constitutional memory. ${ }^{63}$ For the rigidly devout unionist, EVEL - 'English votes for English laws' - should be anathema, but, in terms of political representation at the centre, this it seems is a constitutionally more secular age. Illuminating a strong sense of dissatisfaction with how England is currently governed, the leading attitudinal survey suggests considerable public

\footnotetext{
${ }^{54}$ Daily Record 15 September 2014.

${ }^{55}$ Lord Smith (Chair), Report of the Commission for further devolution of powers to the Scottish Parliament (2014). This is not to overlook the large amounts of technical analysis previously generated in Whitehall: see HM Government, United Kingdom, united future: Conclusions of the Scotland analysis programme $(2014 ; \mathrm{Cm}$. 8869).

${ }^{56}$ See D. Oliver, 'Politics, Law and Constitutional Moments in the UK' in Law in Politics, Politics in Law, ed. D. Feldman (2013).

${ }^{57}$ See for example, House of Lords Constitution Committee, Second Report, Devolution: Inter-institutional relations in the United Kingdom, HL (2002-03) 28.

${ }^{58}$ House of Commons Scottish Affairs Committee, Ninth Report, Legacy Report, HC 1130 (2014-15).

${ }^{59}$ House of Commons Communities and Local Government Committee, First Report, Devolution in England: The Case for Local Government, HC 503 (2014/15).

${ }^{60}$ House of Commons Political and Constitutional Reform Committee, Second Report, A new Magna Carta? HC (2014-15) 463.

${ }^{61}$ HM Government, Scotland in the United Kingdom: An enduring settlement (2015; Cm. 8990).

${ }^{62} \mathrm{HM}$ Government, Powers for a Purpose: Towards a lasting devolution settlement for Wales $(2015$, Cm. 9020), paras. 2.2.10-2.2.19.

${ }^{63}$ David Cameron, speech outside 10 Downing Street, 19 September 2014.
} 
support for this type of approach. ${ }^{64}$ With few (or no) MPs from the other three (Celtic) lands, and faced by the populist challenge of the UK Independence Party, it was only too tempting for the Conservatives to opt for stronger veto powers for English MPs on so-called English legislation than the independent McKay Commission had recommended. ${ }^{65}$ Jumping forward to the fact of a Conservative majority government, another source of friction in the struggle over the Union is identified; the SNP, after all, unlike Sinn Fein, has not adopted a general policy of abstentionism in the House of Commons. ${ }^{66}$ In areas such as policing and criminal justice, English and Welsh MPs would also be counted together by reason of the historic functional motif in central government of 'England and Wales', but probably with significantly less representation from Wales by reason of a review of UK constituency boundaries. ${ }^{67}$ Political contingency again: might this not serve in the medium term to underwrite the case for devolution to Wales in those areas? ${ }^{68}$

\section{HEAVY GOING}

A substantial devolution case-law had already emerged ahead of the Scottish independence referendum; at first largely Scottish in origin and driven by private parties, ${ }^{69}$ but with a dash of the Northern Irish, ${ }^{70}$ and latterly from Wales in inter-governmental litigation linked to the intricacies of the conferred powers model. ${ }^{71}$ Many of the cases involve the doubled protection of human rights with devolution, whereby, alongside the general operation of the Human Rights Act 1998, the Convention rights are part and parcel of the statutory - written constitutions of the three Celtic lands. ${ }^{72}$ Even discounting for the importance of context, however, the jurisprudence is characterised by a variety of approaches. Whereas some judges downplay the constitutional significance of devolution, hence envisaging strict constraints on the young representative institutions, other judges promote the idea of a new and generous constitutional dispensation, while other judges again pursue a more or less middling path. A jurisprudence which the Bingham Centre for the Rule of Law suggests 'has not been entirely consistent ${ }^{73}$ is in my view more like a morass.

Originally argued in May 2014, but with the decision only handed down in February 2015, the Asbestos Diseases case ${ }^{74}$ showcases - if that is the right word - serious judicial disagreement. An innovative Welsh scheme for the recovery from employers/insurers of NHS treatment costs was effectively trumped by powerful commercial interests, so frustrating a redistributive measure passed by a democratically elected legislature under the banner of

\footnotetext{
${ }^{64}$ C. Jeffery et al, Taking England Seriously: The New English Politics (2014).

${ }^{65} \mathrm{Sir}$ W. McKay (Chair), Report of the Commission on the Consequences of Devolution for the House of Commons (2013); HM Government, The Implications of Devolution for England (2014; Cm 8969); Conservative Party, 2015 election manifesto at 70.

${ }^{66}$ As would soon be underlined in the context, no less, of fox hunting: House of Commons debates vol. 598 cols. 743-749 (14 July 2015).

${ }^{67}$ Previously postponed by disagreements in the Cameron/Clegg coalition government; see M. Loughlin and C. Viney, 'The Coalition and The Constitution' in The Coalition Effect, eds. A. Seldon and M. Finn (2015).

${ }^{68}$ See Silk 2, op. cit., n. 26, ch. 10.

${ }^{69}$ Most notably, Whaley v Watson 2000 SC 340; AXA General Insurance Ltd. v Lord Advocate [2011] UKSC 46; Imperial Tobacco Ltd. v Lord Advocate [2012] UKSC 61.

${ }^{70}$ Robinson v Secretary of State for Northern Ireland [2002] UKHL 32.

${ }^{71}$ Local Government Byelaws and Agricultural Sector cases, op. cit., n. 21.

${ }^{72}$ For example, Government of Wales Act 2006, s. 94(6).

${ }^{73}$ Bingham Centre for the Rule of Law, A Constitutional Crossroads: Ways Forward for the United Kingdom (2015), at 59.

${ }^{74}$ Asbestos Diseases case, op. cit., n. 21.
} 
social justice. Referred by the Counsel General for Wales to the UK Supreme Court, with a view to avoiding the uncertainty and expense otherwise associated with private legal action, a friendly in-house challenge had thus taken on a different flavour through third party intervention. Naturally a sore point in Cardiff Bay, the judges not only ruled unanimously against the National Assembly's bill on a narrow ground of retrospectivity, but also divided 3-2 against the legislature on the chief issues of vires in the sense of conferred power and compatibility with the fundamental - Convention - right to peaceful enjoyment of possessions. ${ }^{75}$

The two different approaches adopted in Asbestos Diseases to the compatibility issue, or more precisely the question of the proportionality or otherwise of the National Assembly's intervention under the rubric of public interest, and hence of the degree of deference or respect or weight given by the judges to the exercise of legislative choice, go directly to the constitutional status of the several parliaments and assemblies inside the UK. Elaborated in the minority judgment of Lord Thomas of Cwmgiedd, and there combined with a strong defence of democratic legislative space, one approach is determinedly non-hierarchical in character. Alongside contextual sensitivity to the matter in issue, this is the stuff of each Parliament or Assembly being 'entitled to form its own judgement about public interest ... no logical justification for treating the views of one such body in a different way to the others ... great weight ... attached to the legislative choice made by the Welsh Assembly'. ${ }^{76}$ Reverting to the fact of Wales as a crucible of innovative constitutional thinking, this fits nicely with the First Minister's espousal of a new Union mind-set: greater parity of esteem across the several democratically legitimated centres of authority inside the UK.

Coupled with the according of 'weight' - not 'great weight' - to the National Assembly's legislative choice, the other approach appears in the majority judgment of Lord Mance. Referencing Article 9 of the Bill of Rights 1689 (parliamentary privilege and all that), Lord Mance suggests 'a relevant distinction between cases concerning primary legislation by the United Kingdom Parliament and other legislative and executive decisions'. For which read, cutting to the chase, greater judicial respect for legislation affecting England and little differentiation between the devolved legislatures and other public bodies such as local authorities. ${ }^{77}$ Going directly against the constitutional direction of travel, not least in Scotland, this is a backward-looking approach in more ways than one. As such, I think it constitutional myopic and - yes - unionist folly.

\section{LOCAL TRAFFIC}

In his foreword to the Command Paper Powers for a Purpose: Towards a lasting devolution settlement for Wales, published in February 2015, the Secretary of State Stephen Crabb was suitably forthright: 'it is in the best interests of the people of Wales' that we have a clear devolution settlement which gives them a stronger voice over their own affairs within a strong and successful United Kingdom. ${ }^{78}$ Begun just four months earlier with a deadline of the Welsh festivities on March $1^{\text {st }}$, the cross-party 'St David's Day process' led by the minister had produced consensus on a list of statutory reforms.

\footnotetext{
${ }^{75}$ Article 1 of Protocol 1 of the European Convention on Human Rights.

${ }^{76}$ Asbestos Diseases case, op. cit., n. 21, paras. 118-124.

77 id., paras 56, 67. An alternative approach, not pursued here, would see the devolved legislatures afforded greater latitude than is Westminster in English matters in view of the different consequences of successful challenge (invalidity as against (the weaker declaration of) incompatibility).

${ }^{78}$ HM Government, op. cit., n. 62, foreword.
} 
It does not do to gloss over the differences with the Smith Commission process. The political parties were working first and foremost inside the parameters of the recommendations for further legislative powers made by the independent Silk Commission. ${ }^{79}$ In turn, far from constructing heads of agreement as did the Smith Commission, they engaged in multiple cherry-picking, with consensus, or veto, or no time to discuss, box-ticked in the Command Paper. ${ }^{80}$ The Welsh process was even more closeted than the Scottish one. Unlike the Smith Commission, there were no appointed members, no website, and no published evidence from the political parties (or anyone else). Yes, the Silk Commission had done all this previously; but, in an ever more febrile atmosphere ahead of the UK general election, who now was blocking what, and why? Lacking in the good governance values of transparency, inclusiveness and accountability of which so much has been heard with devolution, ${ }^{81}$ the $\mathrm{St}$ David's Day process was never likely to produce a lasting settlement for Wales; nor has it.

\section{Fuelling}

As regards the fiscal constitution, the usual suspects in Welsh devolution of 'step-by-step' and 'read across' (from Scotland) are clearly in evidence. But also lurking in the shadows is a devolutionary dynamic which typically goes unremarked, but which could in time have particular relevance for Wales: namely, that some have powers thrust upon them.

Following in the footsteps of the Scotland Act 2012, the Wales Act 2014 set in train a process whereby the National Assembly has responsibility for $10 \%$ of all taxes collected in Wales and - subject as the legislation currently stands to a referendum ${ }^{82}$ - for some income tax powers. Block grant from the Treasury, however, is still determined via the well-known Barnett formula, an approach which has clearly operated to Wales' disadvantage. ${ }^{83}$ Inclusion of the formula in the 'vow' to the people of Scotland represents bilateral, back-of-the-envelope, and lop-sided policy-making, to a tee. The St David's Day process has the UK government agreeing to introduce a funding 'floor', so regulating the Barnett-style convergence of Treasury funding per head in Wales to the lower average for England, in 'the expectation' 84 that the Welsh government will call a referendum on income tax powers by 2020 . But with the Command Paper also explaining that the precise level of the 'floor', and the mechanism to deliver it, will only be agreed alongside the next UK Spending Review, ${ }^{85}$ the First Minister has been notably cautious about more fiscal powers for the National Assembly. ${ }^{86}$

Putting this in broader constitutional perspective, a clear framework of relative needs assessment grounded in objective indicators is today nothing less than an article of faith in the Welsh polity. ${ }^{87}$ Good governance values of transparency and legitimacy point firmly in this direction. Indeed, with a view to establishing properly independent institutional machinery, HM Treasury might usefully reflect, not only on comparable arrangements in the Commonwealth, ${ }^{88}$ but also valuable precedents at home such as the Bank of England's

\footnotetext{
${ }^{79}$ Silk 2, op. cit., n 26.

${ }^{80}$ HM Government, op. cit., n. 62, Annex A.

${ }^{81}$ From the very early years: see for example, P. Chaney, New Governance - New Democracy? (2001); also, Women, Politics and Constitutional Change, eds. P. Chaney et al (2007).

${ }^{82}$ Wales Act 2014, ss. 12-14.

${ }^{83}$ Holtham, op. cit., n. 25.

${ }^{84}$ HM Government, op. cit., n. 62, para. 4.10.

85 id., para. 4.9.

${ }^{86}$ Jones, op. cit., n. 37.

${ }^{87}$ Holtham, op. cit., n. 25.

${ }^{88}$ See for example, Bingham Centre, op. cit., n. 73, ch. 6.
} 
Monetary Policy Committee and the Office for Budget Responsibility. ${ }^{89}$ And the more so, it may be said, given the many complications associated with the UK government's fiscal proposals for Scotland, ${ }^{90}$ as well as the clear constitutional merits of devolved fiscal powers in terms of fuelling local policy instruments and lines of democratic accountability. ${ }^{91}$

\section{Higher gear $(s)$ ?}

Wales is currently embarking on a fourth - revamped legislative - phase, with the move to a reserved powers model being virtually a given in the St David's Day process. I have long advocated this type of arrangement for the kinds of reasons articulated in the 2014 Report from the (Silk) Commission on Devolution in Wales: ${ }^{92}$ namely, the linked potentials of greater clarity and consistency, subsidiarity or enhanced policy space in Cardiff Bay, and sharper lines of political accountability. In an evidently doomed attempt to avoid all the frustrations of phases two and three of the Welsh devolutionary journey, I set out a scheme in evidence to the Richard Commission in 2003; naturally, this was closely informed by the model of reserved powers established in the Scotland Act $1998 .{ }^{93}$ A key theme of my evidence was that model and powers go together; the evident advantages of the one being largely dependent in practice on the scale and design of the other. In particular, I said, the wider the range of powers, and the more broadly they are drawn, the less likely that constitutionally enervating legal disputes will arise. And, for good measure, that a cleaner and more generous cut - a constitutional design premised on reducing the legislative grit in the political and administrative system - should appeal to the happy Welsh unionist. ${ }^{94}$

At the heart of day-to-day issues of legislative competence is what I call the connector term; to be precise, the statutory formula 'relates to'. As the shared talisman of different models of devolution the connector works in opposite ways, so referencing, on the one hand, the requirement with conferred powers to find relevant statutory pegs on which to hang policies $;{ }^{95}$ and, on the other, the need with reserved powers to avoid a whole set of legislative hooks. ${ }^{96}$ The reverse dynamics become even clearer if one imagines an alternative connector term: 'falls within'. From the standpoint of the Welsh government, this would be very restrictive with a conferred powers model, but conversely highly liberating with a reserved powers model, which in parentheses is why it is most unlikely to happen.

The burgeoning devolution case-law must be factored into the equation. From the standpoint of the Welsh government, the Supreme Court ruling in the Agricultural Sector case that National Assembly legislation, where it also relates to a subject on which the conferred powers model is silent, is within powers if it 'fairly and realistically' relates to a subject of devolved competence, ${ }^{97}$ was, dare one say it, a green light. Serving to point-up the potential with the move to reserved powers for a roll-back of devolved competence, a different spin is

\footnotetext{
${ }^{89}$ Statutorily established under the Bank of England Act 1998, and the Budget Responsibility and National Audit Act 2011, respectively.

${ }^{90}$ Especially by reason of the so-called 'no detriment' principle, whereby the one government should be protected from the adverse knock-on effects of policy decisions by the other: HM Government, op. cit., n. 61, ch. 2 .

${ }^{91}$ The House of Lords Economic Affairs Committee has announced an inquiry into possible models for devolution of public finances in the UK: call for evidence, 26 June 2015.

92 Silk 2, op. cit., n. 26.

${ }^{93}$ See now A. Page, Constitutional Law of Scotland (2015).

${ }^{94}$ See Rawlings, op. cit., n. 16, chapter 15.

${ }^{95}$ Government of Wales Act 2006, s. 108.

${ }^{96}$ Scotland Act 1998, s. 29.

${ }^{97}$ Agricultural Sector case, op. cit., n. 21, para. 67.
} 
detected at Westminster, namely that the judgment 'made it clear the current model might confer considerably wider powers than the UK government had intended in the 2006 Act' ${ }^{98}$

As an exercise in narrow interpretation, the majority judgment on devolved competence in the Asbestos Diseases case sends the message 'proceed with caution'. Lord Mance was following precedent ${ }^{99}$ with the reading of 'relates to' as demanding 'more than a loose or consequential connection' ${ }^{100}$ But in working with this in formulaic and private law fashion to read down the statutory language of devolved competence in the 2006 Act, his judgment underscores the strict constraints of the conferred powers model. ${ }^{101}$

Constructing a reserved powers model for a small polity long dependent on, and socially and economically integrated with, its larger English neighbour, was always going to be very challenging; and the more so, in view of the constitutionally unique and ever more awkward situation of two legislatures (Cardiff Bay and Westminster) and one legal system ('England and Wales'). Turning this round, the putative move to reserved powers may well, in the not so long view, herald a fifth - legal jurisdictional - phase of Welsh devolution. ${ }^{102}$

The St David's Day process has compounded the drafting problems. Such is the remorseless logic of a situation in which the Silk Commission sensibly combines the reserved powers approach with a substantial set of proposals for further devolution, not least in policing, prisons and criminal justice, ${ }^{103}$ but then substantial parts of these are vetoed, in particular much of anything to do with the Home Office. ${ }^{104}$ The annexes to the Command Paper Powers for a Purpose are instructive. One provides an illustrative list showing the UK government's original thinking on where reservations would be needed. ${ }^{105}$ Oddly, one might think, this proceeds on the basis, not of what was agreed under the St David's Day process, but of the pre-existing arrangements under the conferred powers model. A good clue as to the thoroughgoing technical difficulty of the exercise, as well as - perish the thought disagreement among Whitehall departments, emphasis is placed on the fact that 'the list is not exhaustive, and reservations would also be needed in other areas'. Even so, the list speaks volumes: literally. For which read sprawling items such as 'civil law and procedure' and 'criminal law and procedure', and also a paradigm field for multi-faceted policy development like 'prevention of crime'.

A second annex gives a page-long example of a set of reservations in road transport. ${ }^{106}$ Even this is deceptively simple, illustrating none of the exceptions, let alone 'carve-outs' from those exceptions, liable to mark National Assembly competence over particular aspects of different policy fields. Grimly familiar in Wales from legislative competence orders, ${ }^{107}$ elemental rule of law concerns about clarity and transparency in the constitutional order should not be glossed over. A third annex, ${ }^{108}$ which contains a checklist of matters for

\footnotetext{
${ }^{98}$ House of Commons Library, Wales: Current devolution proposals 2014-15, Standard Note SN/PC/07066 (2015) at 4.

${ }^{99}$ As first developed in Scottish cases: Martin v HM Advocate [2010] UKSC 10, para. 49 (Lord Walker).

${ }^{100}$ Asbestos Diseases case, op. cit., n. 21, para 25.

101 id., paras. 26-27. Conversely, Lord Mance passed over s. 154(2) of the Government of Wales Act 2006, which provides for reading down Assembly Acts in accordance with devolved competence where 'possible'. 102 See Silk 2, op. cit., n. 26, ch. 10.

103 id.

${ }^{104}$ HM Government, op. cit., n. 62, Annex A.

105 id., Annex B.

106 id., Annex C.

${ }^{107}$ See for example, House of Lords Constitution Committee, Twentieth Report, The Proposed National Assembly for Wales (Legislative Competence) (Environment) Order 2009, HL (2008-9)159.

${ }^{108}$ HM Government, op. cit., n. 62, Annex D.
} 
consideration when preparing a reserved powers model for Wales, is highly London-centric. While the pull of UK-wide policy delivery, to ensure that citizens have the same rights and obligations, is properly highlighted, nowhere is this matched with the devolutionary principles of subsidiarity, autonomy and diversity. In speaking of 'silent subjects' considered the sole responsibility of Westminster, the guidance also signals some legislative striking back $^{109}$ at the judicial reasoning in the Agricultural Wages case.

Looking forward, the move to a reserved powers model will demand rigorous scrutiny with a view to ensuring that the legislative scheme is suitably accessible, workable and generous. Following the precedent of the Wales Act 2014, ${ }^{110}$ such a process should involve Welsh ministers in seeking the National Assembly's consent to the provisions modifying devolved legislative competence in the bill, ${ }^{111}$ and hence examination by the National Assembly's Constitutional and Legislative Affairs Committee. This suggests a significant test of the internal maturation of the Welsh polity, especially in view of general elections to the devolved legislatures in May 2016.

First Minister Carwyn Jones has made clear his serious misgivings, indicating that, if the reservation-making gets out of hand, the Welsh government might not advise the National Assembly to give legislative consent. ${ }^{112} \mathrm{Be}$ this as it may, there is far to go if the new statutory framework is to measure up to the admirable sentiments of the Secretary of State in Powers for a Purpose, where he spoke of 'the path to a clear, robust and lasting devolution settlement. ${ }^{113}$ Indeed, in indicating a most picky approach to reserved powers, the Command Paper has raised the spectre of a strange constitutional vehicle: some short legislative parts concerning permanence and competence that flow from the St David's Day process and/or the Smith Commission, followed by page after page after page of what the devolved institutions cannot do. ${ }^{114}$ 'The Wales Act - a contradiction in terms': the very idea should serve as a warning.

\section{SPEEDING ON}

\section{Westminster climes}

Today, the Conservatives bear a heavy burden of responsibility by reason of the conduct as well as the outcome of the UK general election campaign. Repeatedly warning about the prospect of a Labour/SNP coalition was a perfectly legitimate campaign tactic; not least, it may be said, in view of the evident political skill of someone who - ironically - was not standing for election, Scottish First Minister Nicola Sturgeon. Yet it was inevitably the case that, amid all the campaign rhetoric, 'SNP' would commonly be conflated with 'Scotland'. One need not be po-faced to appreciate the dangers for the Union from competing

\footnotetext{
${ }^{109}$ For elaboration of this concept, see C. Harlow and R. Rawlings, "'Striking Back" and "Clamping Down": An Alternative Perspective on Judicial Review' in Public Law Adjudication in Common Law Systems, eds. J. Bell et al (forthcoming).

${ }^{110}$ National Assembly for Wales Constitutional and Legislative Affairs Committee, Legislative Consent Memorandum Report: Wales Bill (June 2014).

${ }^{111}$ UK Cabinet Office, Devolution Guidance Note 17: Modifying the Legislative Competence of the National Assembly for Wales, para. 13; National Assembly for Wales, Standing Order 29 (March 2015 version).

112 Jones, op. cit., n. 40.

${ }^{113}$ HM Government, op. cit., n. 62, foreword.

${ }^{114}$ In contrast, say, to the Scotland Act 1998, where the lists of reservations were naturally combined with the many animating provisions for a parliament and government.
} 
nationalisms when probably the best-known Conservative politician in the south-east of England raises the spectre of something called 'Ajockalypse now'. ${ }^{115}$

To the victor go the spoils. The predictable response from the leader of a majority Conservative government freshly contemplating years of power under the Fixed-term Parliaments Act 2011, David Cameron was very quick to rule out the possible froth of a constitutional convention, or what he caricatured as an 'an enormous talking shop with every faddish idea under the sun'. ${ }^{116}$ Rather, as outlined in their 2015 election manifesto, the Conservatives would press on directly. ${ }^{117}$ Signalling a busy session at Westminster, the new government's programme set out in the Queen's Speech featured a great weight of constitutional legislation, heavily targeted on territorial architecture. A Scotland Bill implementing Smith Commission recommendations, which was duly trumpeted as making the Scottish Parliament 'one of the most powerful devolved parliaments in the world'. ${ }^{118}$ A draft Wales Bill ${ }^{119}$ constructed in the wake of the St David's Day process, which was sufficient to ground the expectation of a statute in the next parliamentary session. A Northern Ireland (Stormont House Agreement) Bill providing for a historical investigations unit in the context of the peace process, which was a key part of the package of institutional, welfare and $\operatorname{tax}^{120}$ reforms agreed for the province in cross-party talks in December $2014 .^{121}$

As for England, a Cities and Local Government Devolution Bill on powers in policy domains such as economic development, transport and social care in return for elected mayors in combined authority areas, ${ }^{122}$ a measure which, if in overly discretionary and patchwork fashion, ${ }^{123}$ grapples with the internal governance aspect of the dreaded 'English question'. ${ }^{124}$ At least it should help to constitutionalise a devolutionary process that, as shown in the trailblazing city region scheme for the 'northern power-house' of Greater Manchester, ${ }^{125}$ has hitherto been cobbled together in strikingly informal, closed and unaccountable fashion. ${ }^{126}$ Not forgetting the victor's touch of EVEL, though proposed changes to House of Commons standing orders, while offering a protectively domestic way forward, have immediately served to expose the practical difficulties of drafting and implementation. ${ }^{127}$

\footnotetext{
${ }^{115}$ Boris Johnson, Sunday Times 3 May 2015.

${ }^{116}$ BBC Wales interview, 14 May 2015.

117 Conservative Party, op. cit., n. 65, at 69-71.

118 Prime Minister's Office, Queen's Speech 2015 - Background Briefing, at 50.

119 The draft Bill has not been published at the time of writing.

${ }^{120}$ See the Corporation Tax (Northern Ireland) Act 2015, passed in the last days of the previous government, which represents another important devolutionary innovation in the UK's fiscal constitution.

${ }^{121}$ Though subsequently proving difficult to implement; see Northern Ireland Office, The Stormont House Agreement (2014); id., Stormont House Agreement: First Progress Report (June 2015). For the earlier development, see C. Knox, Devolution and the Governance of Northern Ireland (2010).

${ }^{122}$ A type of deal strongly pressed by the Chancellor of the Exchequer: George Osborne, speech at Victoria Warehouse, Manchester 14 May 2015.

${ }^{123}$ See House of Lords Constitution Committee, Second Report, Cities and Local Government Devolution Bill, etc. HL (2015-16) 9.

${ }^{124}$ Which came increasingly to the fore as devolution to the three Celtic lands progressed: The English Question, ed. R. Hazell (2005); Institute for Public Policy Research, Answering the English Question: a new policy agenda for England (2008).

${ }^{125}$ HM Treasury, Greater Manchester Agreement (2014). See further, I. Leigh, 'The Changing Nature of the Local State' in The Changing Constitution, eds. J. Jowell et al ( $8^{\text {th }}$ edn., 2015).

${ }^{126}$ See Bingham Centre, op. cit., n. 73, ch. 5.

${ }^{127}$ See UK Cabinet Office, English Votes for English Laws: Revised Proposed Changes to the Standing Orders of the House of Commons (July 2015). At the time of writing, the House of Commons Procedure Committee is conducting an initial review of the proposals. The newly constituted House of Commons Public Administration
} 


\section{Northern lights}

But of course the May 2015 general election produced two winners: not just the Prime Minister with the blue Conservative sash, but also Nicola Sturgeon with the yellow SNP one. Who will best traverse the constitutional moment and who indeed will most whip things up? Alternatively, can David Cameron (and his successors) ride out the storm? And how intense for Wales and the rest of the UK will be the buffeting side-winds? Nor does it detract from the sense of crisis for the Union to point up the major element of gradualism in the SNP's approach, ${ }^{128}$ not least post-referendum. 'We believe in independence but that is not what this election is about'; ${ }^{129}$ as a form of political enticement directed to an end to austerity, and more particularly, in ranging beyond identity politics, to collapsing the unionist Scottish Labour Party like a house of cards, the language of their May 2015 manifesto was cleverly chosen.

Let me refer to a recent report from UCL's Constitution Unit, which usefully synthesises much in a public discussion apt to be weighed down in detail. ${ }^{130} \mathrm{~A}$ set of maps of possible constitutional ways forward is provided in which Scotland naturally features prominently. It is for these Celtic cousins the ever more familiar three models picture: devo more, by which is meant the substantial Smith package already in train; devo even more, for which read 'Smith-plus' extras such as business taxes, employment law and further welfare powers; and devo max, the SNP-style iteration of, on the one hand, 'full fiscal autonomy', and on the other, a most basic Union core (monetary policy, foreign policy, defence and security, citizenship, value added tax). ${ }^{131}$ Underscoring the pace of events, perhaps it was inevitable that devo even more would be a topic of conversation between David Cameron and Nicola Sturgeon within days of the May 2015 election. ${ }^{132}$ With the Smith recommendations effectively banked, and the devolution of 'Smith-plus powers' made a priority in her Party's manifesto, ${ }^{133}$ a buoyant Scottish First Minister could hardly ask for less. And, especially given the attenuated nature of the Smith process, the Prime Minister could scarcely forbear to hear her out.

Self-evidently, the further one goes down the path of devo even more, the greater is the challenge to social citizenship in terms of the pooling and distributing of risks and resources. ${ }^{134}$ Even, however, with a different constellation of political forces, the constitutional conversation in this area is apt to be a continuing one. Successive generations of the welfare state teach that patterns of entitlement are not fixed in stone. A predictable source of disagreement between the members, in deliberating the division of welfare responsibilities the Smith Commission had effectively to navigate the ongoing replacement of means-tested benefits and tax credits at UK-level in terms of 'Universal Credit'. ${ }^{135}$ Relevant provisions in the UK government's draft legislative clauses for the Scotland Bill could not escape forensic examination by the Devolution (Further Powers) Committee at Holyrood. ${ }^{136}$

and Constitutional Affairs Committee has also announced an inquiry into EVEL and the future of the Union: call for evidence, 21 July 2015.

${ }^{128}$ See generally, P. Lynch, The History of the Scottish National Party (2nd edn., 2013).

${ }^{129}$ Scottish National Party, 2015 election manifesto, at 7.

${ }^{130}$ Devolution and the Future of the Union, ed. R. Hazell (2015).

${ }^{131}$ Duly elaborated in evidence to the Smith Commission: Scottish Government, More Powers for the Scottish Parliament (2014).

132 BBC Scotland news 15 May 2015.

${ }^{133}$ Scottish National Party, op. cit., n. 129, at 11.

${ }^{134}$ G. Lodge and A. Trench, Devo More and Welfare (2014).

${ }^{135}$ Smith Commission, op. cit., n. 55, paras. 43-48; BBC Scotland news 28 November 2014.

${ }^{136}$ Devolution (Further Powers) Committee, New Powers for Scotland, SP (2015) 720. 
The legislative proceedings at Westminster will surely involve pressure on UK ministers to expand on the top-up welfare powers for the Scottish Parliament in the Bill as introduced. ${ }^{137}$ Constitutional asymmetry magnified: suffice it to add that, from a Welsh perspective, there is a certain dream-like quality to this development in light of the differential funding levels. A cautious approach on the part of the Welsh government to the accretion of welfare powers, especially top-up ones, is thus readily envisaged, and not only for ideological reasons. Legal authority without the financial resources properly to fuel or animate it is not a good place to be in terms of constitutional and political responsibility.

A somewhat elastic term, devo max was subtly repackaged in the SNP's 2015 manifesto as 'full fiscal responsibility'. ${ }^{138}$ Yet this confederal-type approach could hardly escape a torrent of criticism concerning possible large-scale adverse effects on the public finances in Scotland, and hence for many citizens for whom good unionists should have a care, especially in the light of weakening oil revenues. ${ }^{139}$ Moreover, in constitutional terms, the policy represents a poison-pill for the Union. On the economic side, it raises an Atheniantype question of why all we taxpayers would continue to bear the risks of currency and monetary policy if Union institutions lack effective control of fiscal policy in the member part. And, howsoever diluted in recent times, the social Union would appear but a hollow hope should its institutions be unable to proceed on the basis that poverty neither begins nor ends at the border by Gretna Green.

\section{Late dawn}

As regards the broad institutional framework, it is not difficult to identify a useful set of reforms in London: commonly, however, because they have a lengthy pedigree in the face of Whitehall/Westminster conservatism. Take for example one of the better ideas in Labour's 2015 election manifesto, a Senate of the Nations and Regions. ${ }^{140}$ This obviously is no magic anchor to secure the Union, though it might just help a little. But in constituting a set of voices from across the UK, it is, as against a House of Lords disproportionately composed from certain parts of England, ${ }^{141}$ one form of constitutional improvement.

An old hobby-horse of mine ${ }^{142}$ is the unrealised potential with shared rule and self-rule of basic constitutional desiderata of joint consideration and comity or mutual respect. Although precepts of co-operation, communication and consultation were contained in the original 'soft law ${ }^{143}$ documentation on intergovernmental relations in the $\mathrm{UK},{ }^{144}$ the associated processes were predictably unstable and disjointed, discretionary and closed, and highly dependent on political and administrative goodwill. Indeed, at the birth of devolution to Scotland and Wales, I characterised the intergovernmental system centred on the Joint Ministerial Committee as a 'black hole' at the heart of the UK's new constitutional architecture. ${ }^{145}$

\footnotetext{
${ }^{137}$ Scotland Bill 2015 as introduced, clause 21. For confirmation, see House of Commons debates vol. 597 cols. 1339-1452 (30 June 2015).

${ }^{138}$ Scottish National Party, op. cit., n. 129, at 11.

${ }^{139}$ See especially, Institute for Fiscal Studies, Full fiscal autonomy delayed? (April 2015).

${ }^{140}$ Labour Party, 2015 election manifesto, at 69.

${ }^{141}$ House of Lords Library, Regional Representation in the House of Lords (2014).

${ }^{142}$ R. Rawlings 'Concordats of the Constitution' (2000) 116 Law Q. Rev. 257.

${ }^{143}$ In the broad sense of rules of conduct or pointers and commitments which are not directly legally enforceable; see R. Rawlings, 'Soft Law Never Dies' in The Cambridge Companion to Public Law, eds. M. Elliott and D. Feldman (2015).

${ }^{144}$ Memorandum of Understanding and Supplementary Agreements between the United Kingdom Government, the Scottish Ministers, the Welsh Ministers, and the Northern Ireland Executive Committee (1999 version).

${ }^{145}$ Rawlings, op. cit., n. 142, at 285.
} 
Highlighting the potential for central domination, but also an important role for the system as part of the 'glue' of a reinvented Union, I made a series of recommendations such as statutory underpinning for the JMC, transparency as a guiding principle, and proper parliamentary scrutiny. ${ }^{146}$

Nothing has happened to change my view. The Welsh government for example presents a decidedly mixed picture of shared rule as practiced by Whitehall departments and policy teams, namely 'professional, business-like, constructive, numerous, complex and sometimes frustrating' working relationships. ${ }^{147}$ Meanwhile, testimony to Whitehall inertia during a period of territorial political movement from cosy Labour hegemony to wrangling cohabitation and possible break-up, ${ }^{148}$ a series of recent reports from parliamentary committees and think-tanks rehearses complaints about fragmentation, too little democratic oversight, and, not least in the EU context, organisational skews in favour of London. ${ }^{149}$ Today, an additional premium is placed on an efficient and effective system of intergovernmental relations in view of a (Smith-style) looser Union characterised by more exclusive territorial authority and much shared interest. ${ }^{150}$ Perhaps hopefully, a reference in the Queen's Speech documentation to a revised Memorandum of Understanding on intergovernmental relations, ${ }^{151}$ and also a shake-up in the UK Cabinet Office featuring the development of a UK Governance Group, ${ }^{152}$ shows a new-found determination in Whitehall to address at least some of the concerns.

What, it may be asked, of the full-formed ' $F$ ' word? The argument for an English Parliament will not go away and, on from a burgeoning debate about EVEL, may well grow louder. But Kilbrandon's view that a federal system, strictly conceived, breaks down on the rock of England, has yet to be convincingly challenged. Again, if only with faint echoes of the late failure of Irish home rule, ${ }^{153}$ much of the enticing ambiguity of full-form federalism is lost amid the storm. On from Kilbrandon's somewhat centralist language of preserving unity and desirable flexibility, this particular version of shared rule and self-rule is now increasingly presented as the last, best, hope for the Union. This is no idle point. Allow me to share a dynamic from a recent full-day seminar at Edinburgh University titled 'how federal is Britain?' ${ }^{154}$ Conducted under the Chatham House rule, this brought together not only academics but also a swathe of officials and other influential actors from north of the border. Intellectual origins, comparative perspectives, even a few practical pointers, it all proceeded swimmingly until someone - I wonder who? - asked why the Scottish government would now be interested in discussing full-form federalism. Answer came there none. And this was even before the results of the May 2015 general election.

Let us suppose that, somehow putting to one side the doctrine of parliamentary sovereignty, the UK government started down this path. The issue of a secession clause - where the

\footnotetext{
146 id., at. 259-260, 285-286.

${ }^{147}$ Welsh Government, Written Statement, 8 June 2013.

${ }^{148}$ See further, Governments in Opposition? Intergovernmental Relations in the UK in a Context of Party Political Incongruence, eds. N. McEwen et al (2012).

${ }^{149}$ See for example House of Lords Constitution Committee, Eleventh Report, Inter-governmental relations in the United Kingdom. HL (2014-15) 146, ch. 3; and Institute for Government, Governing in an Ever Looser Union (2015).

${ }^{150}$ Smith Commission, op. cit., n. 55, paras. 28-30.

${ }^{151}$ Prime Minister's Office, op. cit., n. 118, p. 58. The current version of the MoU dates from 2013.

${ }^{152}$ For first fruits, see UK Cabinet Office, Devolution: guidance for civil servants (July 2015).

${ }^{153}$ Government of Ireland Act 1920.

${ }^{154}$ S. Tierney, 'Can the Union Survive the Election?' UK Const. Law Blog 9 May 2015.
} 
border-poll provisions for Northern Ireland ${ }^{155}$ provide a statutory precedent on which to build - would immediately be centre-stage. The very fact of the Scottish independence referendum reinforces a contemporary constitutional understanding that the UK is a voluntary association of nations, with each entitled to opt-out if it so wishes. In the light of statements about the September 2014 vote being a once in a generation opportunity, ${ }^{156}$ the debate in Scotland over when it would be reasonable to hold another independence referendum will no doubt continue. But turning the argument round, the UK government did not claim that September 2014 was an opportunity for independence never to be repeated; and thankfully so, given the strength of the idea of popular sovereignty in Scottish political thought. ${ }^{157}$

Rehearsing the need for a more rounded approach to the territorial constitution, one which incorporates a rich mix of centralist and devolutionary perspectives, the Bingham Centre recently proposed a statutory 'Charter of the Union'. ${ }^{158}$ Mistakenly, in my view, their report immediately links this to the rambling question of a written constitution. More neutral language, a 'Constitutional Renewal Act' perhaps, might also be thought advisable, including from a unionist perspective in the spirit of keep calm and carry on. The Charter itself is presented as a vehicle for what are grandly called 'principles of union constitutionalism', which - ranging considerably beyond Kilbrandon's old specification in terms of democracy and rule of law - extend to matters such as social solidarity and a common economic framework. ${ }^{159}$ If they were properly internalised, such principles could have a useful role to play in guiding legislative and executive processes at UK level. But I am not one for turning substantive principles of this kind into statutory principles of interpretation, hence further invading the domestic political space, as the Bingham Centre, pressing for more judicialisation, particularly advocates. ${ }^{160}$ Even of course if the constitutional slight of no designated Welsh seat on the UK Supreme Court is corrected. ${ }^{161}$

Suppose however that UK ministers, proceeding on the basis that some statutory 'principles of union constitutionalism' are more attractive - viable - than others, were tempted to inject some such legal methodology. Analogous to the principle of 'sincere cooperation' familiar in the EU context, and previously locked in the official documentation of UK intergovernmental relations and waiting to escape, ${ }^{162}$ an overarching principle of comity, trust and fair dealing would be a suitable candidate. Legislative steers bringing a modicum of order to the devolution case law could usefully be added. Happily, the Bingham Centre has already done much of the heavy lifting with an excellent analysis distilling relevant principles from the jurisprudence; or, more accurately, selectively identifying them from the more liberal parts. ${ }^{163}$ A system of government for the UK that is coherent, stable and workable; generous grants of devolved legislative authority; a quartet of parliaments and assemblies that enjoy plenary law-making powers: as principled guidance for determining issues of devolved authority, this is good to go.

\footnotetext{
155 Northern Ireland Act 1998, s 1 and Schedule 1. See further, for recent comparative discussion, D. Haljan, Constitutionalising Secession (2014).

${ }^{156}$ See for example, Scottish Government, Scotland's Future (2013), at i.

${ }^{157}$ As illustrated in the gestation of devolution: Scottish Constitutional Convention, Scotland's Parliament; Scotland's Right (1995).

${ }^{158}$ Bingham Centre, op. cit., n. 73. See also Society of Conservative Lawyers, Our Quasi-Federal Kingdom (2014).

159 id., at 21.

160 id., at 21-22.

${ }^{161}$ See latterly J. Rowe, Review of the process for appointment to The Supreme Court (July 2015).

162 Treaty on European Union, Articles 4(3) and 13(2); Rawlings, op. cit. n. 142, at 267.

${ }^{163}$ Bingham Centre, op. cit., n. 73, Appendix.
} 


\section{Sat nav}

Looking forward, Conservative Party policies on an in/out EU referendum, and on replacing the much maligned Human Rights Act 1998 with a British Bill of Rights, loom large. A tale of two Unions and/or the next fork in the road, a constitutional choreography with the EU referendum can already be sketched. The SNP demands a 'double lock' - actually a quadruple one - whereby the UK remains a Member State unless each home country votes to leave. ${ }^{164}$ The Conservatives duly insist that no, this is an archetypal UK issue. If, as just could possibly happen, the UK votes to separate but Scotland votes better together in the EU, the SNP demand another independence referendum, this time making the fair constitutional point of material change in circumstance from September 2014. Meanwhile, Wales looks on, possibly transfixed.

As for human rights reform, the Conservatives' original policy document talked somewhat darkly of working with the devolved institutions 'as necessary' in order to ensure an effective new settlement across the UK. ${ }^{165}$ We touch here on some highly convoluted issues of constitutional and international law, rendered more difficult by the absence of precise legislative proposals in the light of new-found ministerial interest in public consultation. ${ }^{166}$ Matters are compounded by fundamental differences between the various devolutionary frameworks: the Good Friday Agreement stipulating incorporation of the European Convention on Human Rights in Northern Ireland; ${ }^{167}$ the Scottish Parliament under their reserved powers model seemingly able to legislate on human rights but not to modify the Human Rights Act; ${ }^{168}$ and Cardiff Bay heavily constrained in key intersecting policy areas or by reason of the unified legal system of England and Wales. Tucking in behind Scottish institutions firmly committed to Convention rights, and making great play with the Sewel Convention, could well have major attractions for Welsh ministers and officials. Whitehall would do well, in a situation infused with territorial constitutional values, to be cautious. In the continuing struggle over the Union, some fights are better picked than others. A case like Asbestos Diseases cannot obscure the place of Convention rights as part of the young polities' DNA. ${ }^{169}$

\section{CONCLUSION}

We are not yet at the end of the Union, nor are we in Churchillian terms at the end of the beginning. The question which faces us is rather whether this is the beginning of the end for the Union and no-one knows the answer to that. Self-evidently, however, the chances are much increased - as present day efforts at making the Union framework more robust serve in part to underline. Moods change, but at least for the time being 'the wind is in the north'.

Several things can be said with confidence. First, from the Welsh perspective, this small polity is still being all too often buffeted about. The price of devolution, the St David's Day process reminds us, is eternal vigilance. The approach to reserved powers advertised in the Command Paper Powers for a Purpose is the type of arrant pedantry up with which Wales

\footnotetext{
${ }^{164}$ Scottish National Party, op. cit., n. 129, at 9.

165 Conservative Party, Protecting Human Rights in the UK (2014), at 6.

166 Prime Minister's Office, op. cit., n. 118, at 75.

167 See Northern Ireland Office, The Belfast Agreement (1998), Strand One: safeguards.

168 Scotland Act 1998, Schedule 4, Part 1.

${ }^{169}$ See for example, A Sherlock, 'Human Rights in the National Assembly for Wales', in Parliaments and Human Rights, eds. M. Hunt, H. Hooper and P. Yowell (2015).
} 
should not put. Now that this is highlighted, the extent to which the approach is carried through into the upcoming Wales Bill will be a key litmus test of constitutional sensibility on the part of the new UK Conservative government.

Secondly, the failure to heed our Welsh soothsayers and take seriously the need for a widely informed and rounded approach to the UK's territorial constitution ahead of the Scottish independence referendum is a serious blot on the record of the Cameron-Clegg coalition government. The car crash that was Kilbrandon warns against any easy assumption that a more stable and coherent system of governance would have resulted, not least for England. But from a unionist perspective just about anything would have been preferable to the stormforce conditions of the 'vow'. Thirdly, if the Union is to make good a reprieve in the Scottish independence referendum, this will require political skills and statesmanship of a very high order. There is no quick fix, and in this particular multinational democracy that includes fullform federalism. Fourthly, a case of playing institutional catch-up, the continuing need to reconfigure key modalities of shared rule as well as self-rule in the Union will be of the essence of territorial constitutional reform in the next period. The chimera of heavy doses of law calming the storm should not obscure this major opportunity for constitutional improvement.

Lastly, the need for principles of mutual benefit, comity and parity of esteem to inform constructive and flexible federal-type responses at UK level inside a famously uncodified constitution deserves special emphasis. Without joined-up constitutional thinking at Westminster along these lines, and associated changes in the workings of the post-imperial Whitehall machine, the next period of our constitutional futures in this cluttered isle is even more likely to prove tempestuous. 